\section{Ilmo. Senhores}

Bernardo Gontijo, Silvio Marques, Everton do Vale

MD. Editores dos Anais Brasileiros de Dermatologia

\section{Classificação das doenças pré-cancerosas}

Senhores Editores,

Dois livros importantes da dermatologia brasileira (Azulay \& Azulay, Sampaio \& Rivitti) referem-se a inúmeras doenças pré-cancerosas. O objetivo desta correspondência é sintetizar o assunto de maneira útil e compreensível, propondo o que se segue.

\section{Dermatoses pré-cancerosas}

1 - Afecções cancerináveis: as duas mais importantes são:

- úlcera na perna que depois de aproximadamente 10 anos apresenta lesões proliferativas em sua borda;

- lesão ulcerada que possa surgir em quadro de hipopigmentação generalizada.

2 - Estados cancerígenos: há inúmeras genodermatoses que podem transformar-se em câncer cutâneo, quando a criança se expõe ao sol. É impossível impedir que uma criança vá à rua e, portanto, se exponha ao sol. Esse fato implica o aparecimento precoce de câncer cutâneo, na puberdade. O xeroderma pigmentar é o exemplo maior dessa condição.
3 - Blastóides: nesse grupo foram incluídas duas dermatoses principais: doença de Bowen e doença de Paget. A doença de Bowen caracteriza-se pela apresentação de lesões eritêmato-infiltradas descamativas disseminadas; quando uma dessas lesões ulcera é porque se transformou em epitelioma espinocelular. A doença de Paget é muito curiosa: caracteriza-se pelo aparecimento de lesão eczematizada de um dos mamilos (quer no homem ou na mulher); chama-se atenção para o fato de que a eczematização bilateral do mamilo é relativamente comum e depende da cor ou da textura do tecido usado. Entretanto, quando essa eczematização, tanto no homem como na mulher, ocorre unilateralmente, se está diante de uma doença de Paget que se pode cancerizar, atingindo gânglios, pulmões e até mesmo o cérebro.

Dessa maneira, pensa-se ter conseguido a transformação de uma lesão aparentemente simples (eczematização unilateral) em câncer grave e possivelmente mortal.

Concluindo: procurou-se demonstrar casos aparentemente simples que podem transformar-se em doença grave, como é o câncer.

Atenciosamente,

Rubem David Azulay

Membro da Academia Nacional de Medicina 